\title{
ESTIMASI PERTUKARAN GAS CO 2 LAUT-UDARA DI PERAIRAN SIMEULUE PADA MONSUN ASIA MUSIM PANAS
}

\section{ESTIMATION OF SEA-AIR CO EXCHANGE AT SIMEULUE SEA DURING SUMMER ASIAN MONSOON}

\author{
Lamona I. Bernawis ${ }^{1 *}$, Iwan P. Anwar' ${ }^{1}$, Ahmad Bayhaqi ${ }^{2}$, Aan J. Wahyudi², \\ Mutiara R. Putri ${ }^{1}$ dan Muhammad Fadli ${ }^{3}$ \\ ${ }^{1}$ Kelompok Keahlian Oseanografi, FITB-ITB, Bandung, 40132, Indonesia \\ ${ }^{2}$ Pusat Penelitian Oseanografi, LIPI, Jakarta, 14430, Indonesia \\ ${ }^{3}$ Pusat Penelitian Laut Dalam, LIPI, Ambon, 77233, Indonesia \\ *E-mail: lamona@ fitb.itb.ac.id
}

\begin{abstract}
The summer Asian monsoon (onset summer of Asia monsoon) occurs in June-July-August. The sea around Simeulue Island, Aceh, is affected by upwelling from the Indian Ocean. Within this period the effect of the carbon dioxide gas cycle between the sea and air in the area around the Island is predicted. The 2017 \#coastal chapter Widya Nusantara (EWIN) Expedition Survey conducted in conjunction with the Research Center for Oceanography (P2O) LIPI in July 2017 obtained data on temperature, salinity and partial pressure of $\mathrm{CO}_{2}$ gas in the sea $\left(\mathrm{pCO}_{2} \mathrm{Sea}\right)$. The objective is to investigate the ocean-atmosphere interaction and to determine the source or sink of carbon around the Island. The $\mathrm{CO}_{2}$ data in the atmosphere obtained from the Bukit Kototabang Global Atmospheric Monitoring Station, West Sumatra. By calculating $\mathrm{CO}_{2}$ flux between sea and air, the results show that the western region of the island acts as carbon sinks with a flux value of $-0.05 \mathrm{~mol} \mathrm{C} / \mathrm{m}^{2}$ days to -0.25 mol $C / \mathrm{m}^{2}$ days. Meanwhile in the eastern region of the island roles as carbon source with a flux value of $0.05 \mathrm{~mol} \mathrm{C} / \mathrm{m}^{2}$ day to $0.2 \mathrm{~mol} \mathrm{C} / \mathrm{m}^{2}$ day. The value of positive/negative flux means that the sea releases/absorbs carbon into the air, respectively.
\end{abstract}

Keywords: EWIN 2017, sea-air carbon dioxide flux

\begin{abstract}
ABSTRAK
Saat awal monsun Asia musim panas (onset summer of Asia monsoon) di bulan Juni-Juli-Agustus, perairan sekitar Pulau Simeulue, Aceh, terpengaruh oleh kejadian upwelling di Samudra Hindia. Hal ini diduga mempengaruhi siklus gas karbondioksida antara laut dan udara di perairan sekitar Pulau Simeulue, Aceh. Pada kegiatan survei Ekspedisi Widya Nusantara (EWIN) 2017 \#coastal chapter yang dilaksanakan bersama Pusat Penelitian Oseanografi (P2O) LIPI bulan Juli 2017 didapat data temperatur, salinitas dan tekanan parsial gas $\mathrm{CO}_{2}(\mathrm{pCO} 2)$ di laut. Tujuan dari penelitian ini adalah untuk melihat interaksi laut-atmosfer dan menentukan serapan atau luaran karbon di sekitar Pulau Simeulue. Untuk data pendukung berupa kadar $\mathrm{CO}_{2}$ di udara didapat dari Stasiun Pemantau Atmosfer Global Bukit Kototabang, Sumatra Barat. Dengan melakukan perhitungan flux $\mathrm{CO}_{2}$ antara laut dan udara, didapatkan hasil bahwa perairan di wilayah barat pulau berperan sebagai penyerap karbon (sink) dengan nilai fluks $-0,05 \mathrm{~mol} \mathrm{C} / \mathrm{m}^{2}$ hari hingga $-0,25 \mathrm{~mol} \mathrm{C} / \mathrm{m}^{2}$ hari. Sementara itu pada wilayah timur pulau memiliki peran sebagai sumber karbon (source) dengan nilai fluks $0,05 \mathrm{~mol} \mathrm{C} / \mathrm{m}^{2}$ hari hingga $0,2 \mathrm{~mol} \mathrm{C} / \mathrm{m}^{2}$ hari. Nilai fluks positif berarti laut melepaskan karbon ke udara dan sebaliknya nilai negatif berarti laut menyerap karbon.
\end{abstract}

Kata kunci: EWIN 201, pertukaran gas karbondioksida laut dan udara 


\section{PENDAHULUAN}

Pulau Simeulue terletak $150 \mathrm{~km}$ lepas pantai Barat Aceh di Pulau Sumatra dan berada di Samudra Hindia. Perairan yang mengelilingi Pulau Simeulue untuk selanjutnya disebut Perairan Simeulue terletak diantara $2^{\circ} 15^{\prime} 03^{\prime} '-02^{\circ} 55^{\prime} 04$ ' 'LU dan 95'40'15' '-96'30'45'BT (Percepatan Pembangunan Sanitasi Pemukiman Simeulue, 2013). Gugusan pulau di Simeulue berjumlah 147 pulau dan bukan merupakan kepulauan vulkanik. Ekosistem pesisir yang terdapat di sekitar Pulau Simeulue antara lain ekosistem lamun, mangrove, dan karang.

Kondisi iklim di kepulauan ini memiliki curah hujan sebesar 3.346,50 $\mathrm{mm} / \mathrm{tahun}$ dengan 253 hari hujan (Rahmantya et al., 2016). Temperatur udara berkisar antara $25-33^{\circ} \mathrm{C}$ dan kelembaban nisbi antara 60-75\%, serta kecepatan angin rata-rata sebesar $1,5 \mathrm{~m} / \mathrm{s}$ (Rahmantya et al., 2016). Wilayah perairan tersebut sangat dipengaruhi oleh variasi musim, terutama musim di Asia. Selama musim panas di Asia, umumnya pada bulan Juni-Juli-Agustus, arus laut bergerak dari barat laut menuju tenggara; dan pada musim dingin Asia, umumnya mulai bulan Desember-Februari tahun berikutnya, arus bergerak dari tenggara menuju barat laut (Wyrtki, 1961; Eltrik, 2016). Antara musim dingin dan musim panas Asia, terdapat kondisi peralihan atau awal dimulainya musim dinamakan onset monsoon yang umumnya terjadi pada bulan April-Mei dan Oktober-November. Pada musim peralihan, angin di atas ekuator Samudra Hindia didominasi angin baratan yang membangkitkan arus ekuator (Wyrtki jet) ke arah timur dengan kecepatan maksimum 0,5 m/detik pada bulan Mei (Mardiansyah dan Iskandar, 2014). Arus ekuator ini pada saat mencapai pantai Barat Sumatra akan bergerak menuju Selatan Jawa dan sebagian bergerak ke utara hingga ke Selat Malaka (Tomczak and Godfrey, 2001). Arus ekuator memegang peranan penting dalam distribusi massa air, bahang dan salinitas yang selanjutnya akan membentuk suhu permukaan laut (SPL) di ekuator Samudra Hindia (Masumoto et al., 2005).

Kondisi angin pada saat musim panas Asia diperkirakan sangat ber-pengaruh terhadap kondisi ekosistem Perairan Simeulue, bagian barat pulau menghadap ke Samudra Hindia dan di bagian timur menghadap ke Pulau Sumatra. Kondisi suhu perairan yang hangat akan memicu penguapan air yang akan meningkatkan curah hujan lokal, yang dirasakan saat survei. Selain itu, peningkatan suhu menyebabkan pelepasan gas $\mathrm{CO}_{2}$ untuk selanjutnya dapat me-nurunkan $\mathrm{pH}$ perairan.

Berdasarkan dinamika yang terjadi pada perairan Simeulue dan sekitarnya, penyerapan dan pelepasan $\mathrm{CO} 2$ di-perkirakan berlangsung secara dinamis. Untuk itu, kajian pertukaran gas $\mathrm{CO}_{2}$ laut udara saat musim panas Asia di Perairan Simeulue sangat perlu dilakukan dalam rangka menjaga ekosistem yang ber-kelanjutan.

\section{METODE PENELITIAN}

\subsection{Waktu dan Tempat Penelitian}

Pengambilan data dilakukan bersama dengan kegiatan Ekspedisi Widya Nusantara (EWIN) 2017 \#costal chapter yang dikelola oleh Pusat Penelitian Oseanografi - Lembaga Ilmu Pengetahuan Indonesia (P2O - LIPI) pada tanggal 25-28 Juli 2017 di wilayah perairan Pulau Simeulue, Aceh. Gambar 1. menunjukkan daerah penelitian dan titik-titik stasiun pengamatan selama kegiatan berlangsung. Kedalaman perairan di bagian timur Pulau Simeulue berkisar antara $10 \mathrm{~m}$ $1000 \mathrm{~m}$, sedangkan pantai barat berkisar antara 10 m-3000 m (Eltrik, 2016).

\subsection{Metode Pengambilan Data}

Pengukuran parameter $\mathrm{pCO}_{2}$ secara kontinu berjalan (underway). Kapal ber-jalan sepanjang jalur yang ditentukan dari satu titik ke titik stasiun berikutnya (Gambar 1) dengan rata-rata kecepatan sekitar 8 Knot. Data suhu dan salinitas diukur menggunakan 
Conductivity Temperature Depth (CTD) tipe SBE 911+ pada 28 stasiun di bagian timur, selatan, hingga ke barat Pulau Simeuleu (Gambar 1).

Alat ukur $\mathrm{pCO}_{2}$ yang digunakan adalah Mini Pro $\mathrm{CO}_{2}$ Pro Oceanus. Alat ukur $\mathrm{pCO}_{2}$ diatur untuk merekam data dengan selang waktu 5 detik dan disesuaikan dengan selang waktu perekaman posisi oleh Global
Position System (GPS) tipe Garmin 78 Sea. Air laut dari permukaan $( \pm 1 \mathrm{~m}$ kedalaman maksimum) dipompa menuju dasar bak penampungan air dan langsung keluar. Air yang dipompa dari laut mengalir masuk ke dasar bak ini lah yang diukur nilai $\mathrm{pCO}_{2}$ nya, sehingga tidak terkontaminasi $\mathrm{pCO}_{2}$ dari atmosfer (lihat Gambar 2).

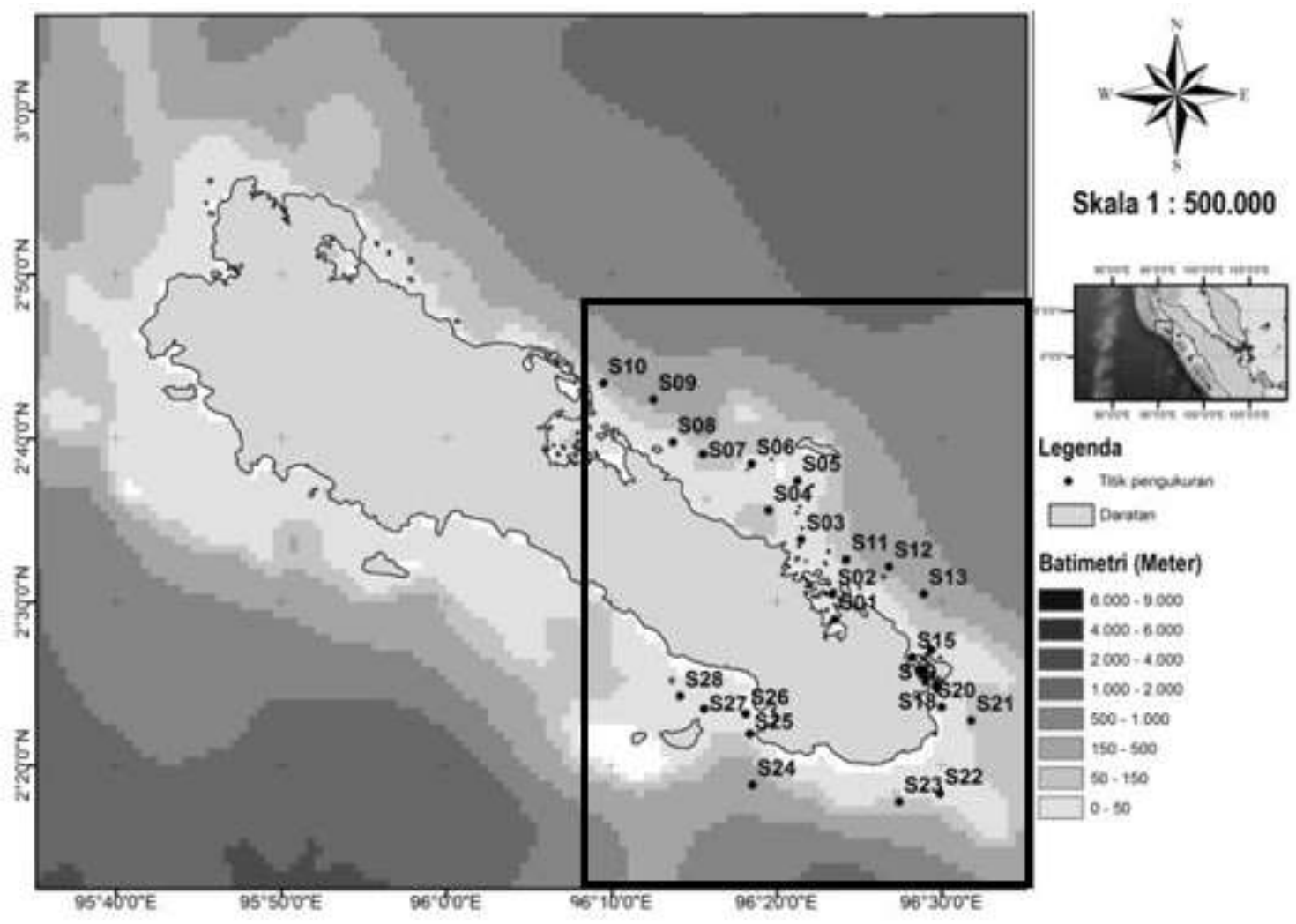

Gambar 1. Peta batimetri di sekeliling Pulau Simeuleu (Sumber data: GEBCO, 2016).

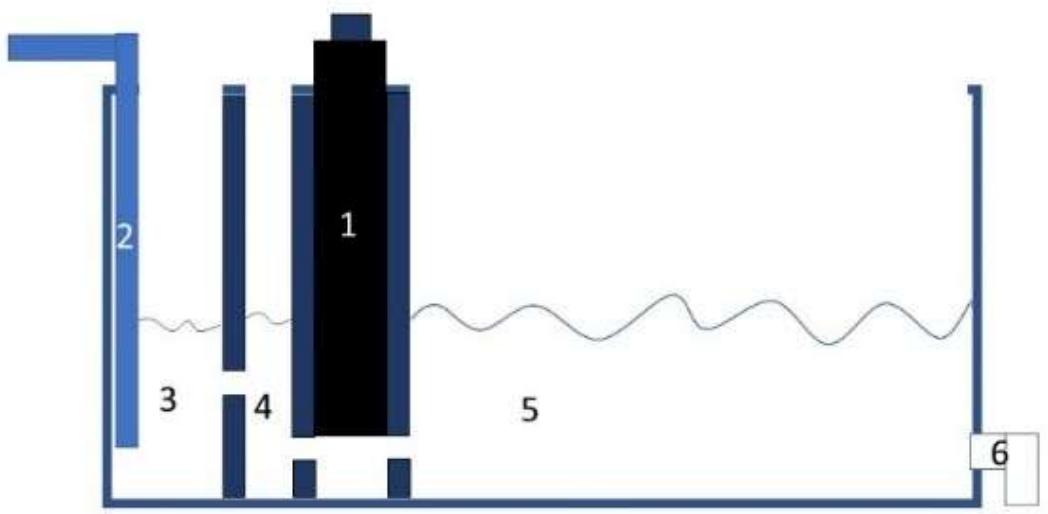

Keterangan

1. $\mathrm{pCO}_{2}$ Sensor

2. Air dari pompa

3. Tandon peredam buih 1

4. Tandon peredam buih 2

5. Tandon air untuk sensor lainnya (i.e. suhu, salinitas, $\mathrm{pH})$

6. Air pembuangan

Gambar 2. Sketsa pengukuran $\mathrm{pCO}_{2}$ laut tampak samping. 


\subsection{Sumber Data Pendukung}

Selain data primer, digunakan pula data pendukung berupa kecepatan angin di ketinggian $10 \mathrm{~m}$, yang diunduh dari The European Centre for Medium-Range Weather Forecasts (ECMWF) (laman http://apps.ecmwf.int). Data kecepatan angin tersebut memiliki grid horizontal $0,75^{\circ} \mathrm{x}$ $0,75^{\circ}$ dan selang waktu tiap 6 jam. Data tersebut akan digunakan untuk menghitung laju pertukaran gas karbondioksida antara laut dan udara.

Selain itu digunakan data konsentrasi karbondioksida di atmosfer yang diukur oleh Stasiun Pemantau Atmosfer Global Bukit Kototabang-Badan Meteorologi Klimatologi dan Geofisika (BMKG) dan diunduh dari laman https://www.esrl.noaa.gov/gmd/dv/site /BKT.html. Data konsentrasi $\mathrm{CO}_{2}$ ini ditampilkan dalam rata-rata bulanan pada laman tersebut, dengan nilai sebesar 402,08 ppm pada bulan Juli 2017. Data karbondioksida di atmosfer ini digunakan untuk menghitung suatu daerah di perairan sebagai sink atau source dari gas karbon dioksida.

\subsection{Metode Interpolasi Spasial}

Data yang didapat dari hasil pengukuran berupa temperatur, salinitas, dan $\mathrm{pCO}_{2}$ Laut dan data lain yang didapat dari hasil pendukung berupa kecepatan angin dan konsentrasi $\mathrm{CO}_{2}$ Udara. Sebelum dihitung flux pertukaran gas $\mathrm{CO}_{2}$ laut-udara, seluruh parameter tersebut harus memiliki ukuran grid yang sama. Sehingga seluruh data dilakukan interpolasi spasial. Interpolasi yang digunakan menggunakan metode kriging. Metode tersebut mem-bangun model spasial dari hasil data yang dimiliki dengan melihat bentuk variogram-nya (ESRI, 2001).

\subsection{Perhitungan Pertukaran Gas $\mathrm{CO}_{2}$ Laut Udara}

Nilai pertukaran gas karbondioksida (Wanninkhof, 1992) dapat ditentukan sebagai aliran fluks $\left(F, \mathrm{~mol} \mathrm{C} / \mathrm{m}^{2}\right.$ hari) karbon antara laut dan udara dengan perkalian koefisien transfer gas $(k, \mathrm{~cm} / \mathrm{jam})$, kelarutan gas karbon dalam air laut ( $S b, \mathrm{~mol} / \mathrm{m}^{3}$ atm), dan perbedaan tekanan parsial karbondioksida antara laut dan udara $\left(\triangle p \mathrm{CO}_{2}, \mathrm{ppm}\right.$ atau $\mu \mathrm{atm})$, seperti ditunjukkan oleh Persamaan (1) berikut:

$$
F=k \cdot S b \cdot \Delta p \mathrm{CO}_{2}
$$

Jika $F$ atau fluks (mol $\mathrm{C} / \mathrm{m}^{2}$ hari) pada persamaan (1) bernilai positif, maka konsentrasi $\mathrm{CO}_{2}$ di laut lebih besar dibandingkan di udara dan terjadi perpindahan konsentrasi karbondioksida dari laut ke atmosfer atau laut melepaskan karbon ke atmosfer (source). Sebaliknya jika nilai $F$ negatif, maka laut menyerap karbon ke atmosfer $(\sin k)$.

Persamaan (2) menghitung kecepatan transfer gas atau $k(\mathrm{~cm} / \mathrm{jam})$ dari laut ke udara atau sebaliknya (Ho et al., 2006). Kecepatan transfer gas ini dihitung berdasarkan kecepatan angin yang bertiup pada ketinggian $10 \mathrm{~m}\left(U_{10}\right)$. Makin besar kecepatan angin, maka makin besar transfer yang terjadi. Persamaan (2) ini digunakan karena dapat diterapkan pada daerah yang memiliki kecepatan angin hingga lebih dari $15 \mathrm{~m} /$ detik, seperti angin yang dapat terjadi di barat Sumatra atau Samudra Hindia pada umumnya.

$$
k=0,266 \cdot U_{10^{*}}^{2}\left(\frac{660}{S c}\right)
$$

Pada persamaan (2) varibel $S c\left(\mathrm{~mol} / \mathrm{m}^{3}\right.$ atm) atau Schmidt Number adalah koefisien normalisasi dan dihitung dengan menggunakan Persamaan (3).

$$
S c=A-B T+C T^{2}+D T^{3}
$$

Dimana $T$ adalah temperatur $\left({ }^{\circ} \mathrm{C}\right)$, sedangkan A, B, C dan D adalah konstanta polinomial least square orde ketiga untuk kondisi air laut dengan suhu antara $0-30^{\circ} \mathrm{C}$. Besar konstanta $\mathrm{A}, \mathrm{B}, \mathrm{C}$ dan $\mathrm{D}$ untuk $\mathrm{CO}_{2}$ berturut- 
turut adalah 2073,1, 125,62, 3,6276 dan 0,043219 (Wanninkhof, 1992).

Fluks gas karbondioksida (persamaan 1) juga dipengaruhi oleh kelarutan dari sebuah gas dalam air laut. Secara matematis kelarutan $(S b)$ dapat dihitung dengan persamaan (4) seperti dijelaskan oleh Weiss (1974) dalam Wanninkhof (1992):

$$
\begin{aligned}
& \ln S b=A 1+A 2 \cdot\left(\frac{100}{T}\right)+ \\
& A 3 \cdot \ln \left(\frac{T}{100}\right)+S\left[B 1+B 2\left(\frac{T}{100}\right)+\right. \\
& \left.B 3 \cdot\left(\frac{T}{100}\right)^{2}\right]
\end{aligned}
$$

Dengan $\mathrm{Sb}$ merupakan kelarutan gas $\mathrm{CO}_{2}$ ( $\mathrm{mol} / \mathrm{m} 2 \mathrm{~atm}), \mathrm{T}$ merupakan temperatur dalam Kelvin dan $\mathrm{S}$ adalah salinitas dalam psu. Sementara itu A1, A2, A3, B1, B2, dan B3 adalah konstanta yang nilainya berturutturut adalah -60,2409, 93,4517, 23,3585, 0,023517, -0,023656 dan 0,0047036 (Weiss, 1974 dalam Wanninkhof, 1992).

\section{HASIL DAN PEMBAHASAN}

\subsection{Kondisi Fisik Air Laut Perairan Simeulue}

Perairan Simeulue merupakan perairan yang terpengaruh oleh Samudra Hindia di bagian barat dan di bagian timur yang terpapar proses daratan Sumatra. Pengaruh Samudra Hindia pada saat musim panas Asia di perairan bagian selatan dan tenggara Pulau Simeuleu, adalah proses upwelling. Hal ini ditunjukkan adanya suhu yang lebih dingin dan salinitas tinggi naik ke permukaan (Gambar 3).

Suhu air laut yang mulai menurun tersebut bersesuaian dengan kejadian monsun Asia musim panas yang me-nyebabkan massa air di Samudra Hindia dan Teluk Benggala lebih dipengaruhi massa air dari Arab dan Somalia yang memiliki suhu 24$30^{\circ} \mathrm{C}$ dan salinitas 35,5-36,8 psu (Tomczak and Godfrey, 2001). Hal ini terjadi karena arus permukaan di perairan barat Sumatra bagian utara bergerak dari tenggara pada musim panas Asia bulan Juni hingga September. Pengaruh lokal terjadi di pesisir yang memiliki ekosistem mangrove dan daerah pelabuhan yang memiliki aktivitas yang cukup tinggi. Pada daerah pelabuhan dan ekosistem mangrove suhunya berkisar antara 30,4-30,5 ${ }^{\circ} \mathrm{C}$, sedangkan untuk wilayah perairan yang berhadapan dengan Samudra Hindia suhunya berikisar antara $29,8-30^{\circ} \mathrm{C}$.

Salinitas berkisar antara 33,75-33,90 psu untuk perairan yang berhadapan dengan Samudra Hindia dan bernilai 33,75-33,8 psu untuk wilayah yang berada di timur Pulau Simeulue. Rata-rata kondisi perairan Simeulue pada musim panas Asia bulan Juli memiliki suhu pada kisaran $29-31^{\circ} \mathrm{C}$ dan salinitas 33,5-34 psu. Hal itu sesuai dengan penelitian sebelumnya yang dilakukan oleh Eltrik (2016).

Fenomena tersebut akan berpengaruh terhadap konsentrasi karbon-dioksida di Perairan Simeulue. Konsentrasi $\mathrm{pCO}_{2}$ di laut dapat dipengaruhi oleh proses fisik dan biokimia yaitu besarnya suhu, salinitas permukaan laut, dan fotosintesis oleh aktifitas klorofil-a (Millero, 2005).

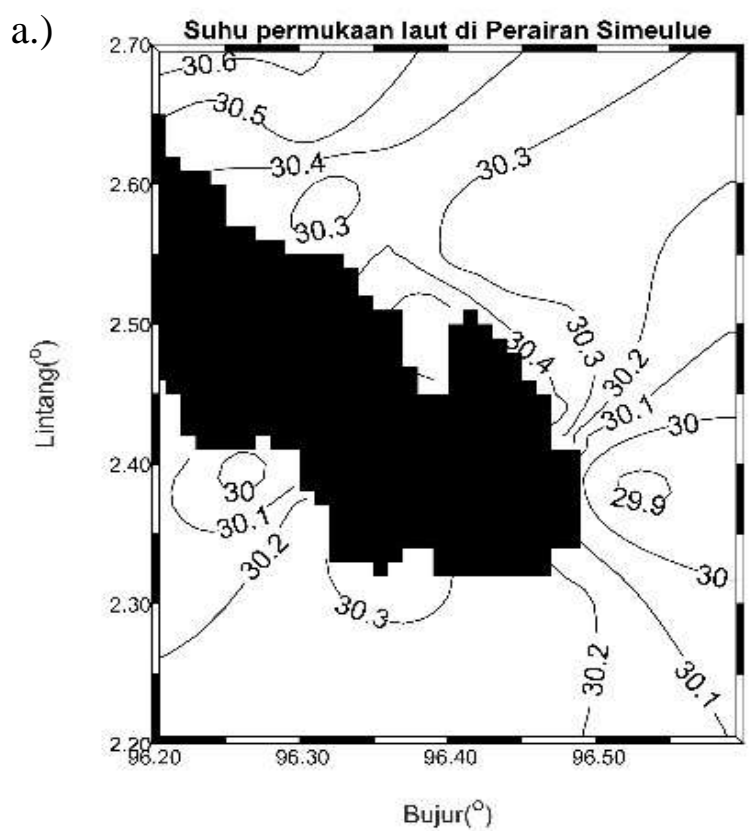




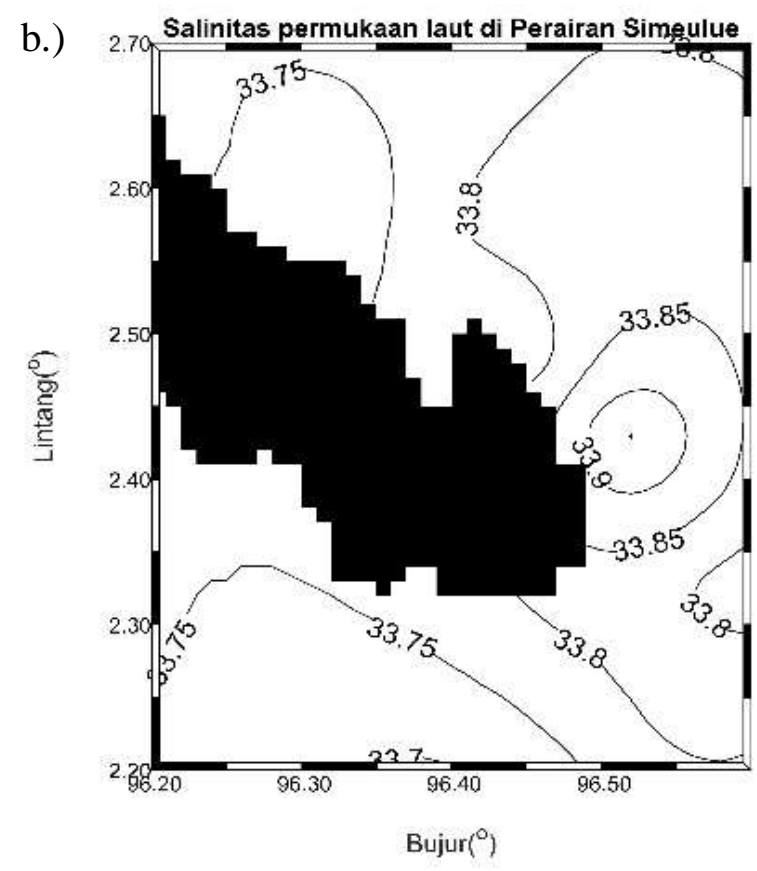

Gambar 3. Suhu (a) dan Salinitas (b) permukaan air laut di Perairan Simeulue 25-28 Juli 2017.

\subsection{Estimasi Pertukaran $\mathrm{CO}_{2}$}

Berdasarkan hasil survei pada tanggal 25-28 Juli 2017 diperoleh sebaran $\mathrm{pCO}_{2}$ di Perairan Simeulue, seperti yang ditunjukan oleh Gambar 4a. Secara umum sebaran $\mathrm{pCO}_{2}$ di perairan Simeulue dipengaruhi oleh faktor lokal, seperti adanya aktivitas pelabuhan dan daerah ekosistem mangrove, serta di bagian barat adanya Samudra Hindia. Perairan yang berhadapan dengan tempat aktivitas manusia atau kota, pelabuhan, dan ekosistem mangrove memiliki konsentrasi $\mathrm{pCO}_{2}$ berkisar antara 420-430 ppm. Sementara itu wilayah yang berhadapan dengan Samudra Hindia memiliki nilai $\mathrm{pCO}_{2}$ yang lebih rendah, yaitu berada pada kisaran 385-405 ppm seperti ditunjukkan pada Gambar 4a.

Secara umum estimasi flux karbondioksida dihitung dengan melihat selisih antara kadar karbondioksida laut dan udara.
Pada penelitian ini nilai karbondioksida udara yang digunakan diasumsi-kan seragam secara ruang dengan nilai 402,08 ppm mengacu pada data Stasiun Pemantau Atmosfer Global Bukit Koto-tabang-Badan Meteorologi Klimato-logi dan Geofisika (GAW-BMKG). Asumsi ini sahih dan umum digunakan karena luasan ruang di atas Pulau Simeulue kecil dan menggunakan data ruang udara terdekat dari GAW-BMKG. Estimasi sebaran fluks karbondioksida di perairan Simeuleu dari hasil pengukuran $\mathrm{pCO}_{2}$ ditunjukan oleh Gambar 4b. Nilai fluks positif, antara 0,05 hingga $0,2 \mathrm{~mol} \mathrm{C} / \mathrm{m}^{2}$ hari berada di bagian timur perairan, yang menghadap ke Pulau Sumatra. Wilayah perairan yang di-pengaruhi oleh aktivitas manusia (kota dan pelabuhan) dan ekosistem mangrove. Sementara itu untuk perairan yang meng-hadap ke Samudra Hindia, yaitu bagian barat Pulau Simeuleu) memiliki nilai fluks yang negatif, yaitu antara -0,05 hingga $0,25 \mathrm{~mol} \mathrm{C} / \mathrm{m}^{2}$ hari. Hal ini menunjukkan di bagian barat pulau terjadi penyerapan karbon pada bulan Juli dan diperkirakan selama musim panas Asia mulai bulan Juni hingga September.

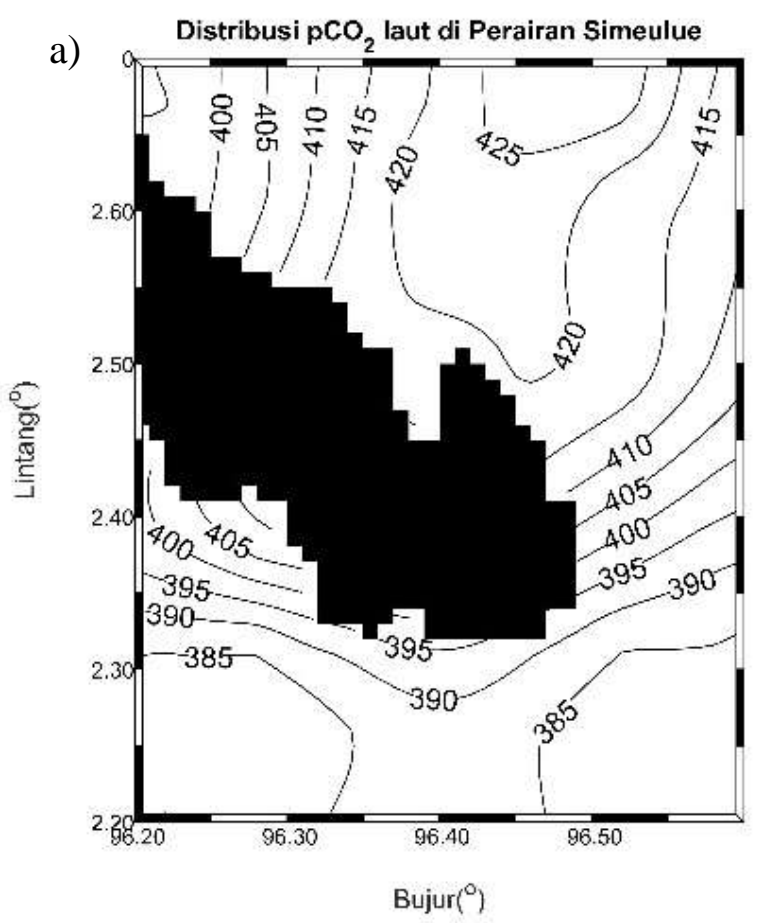




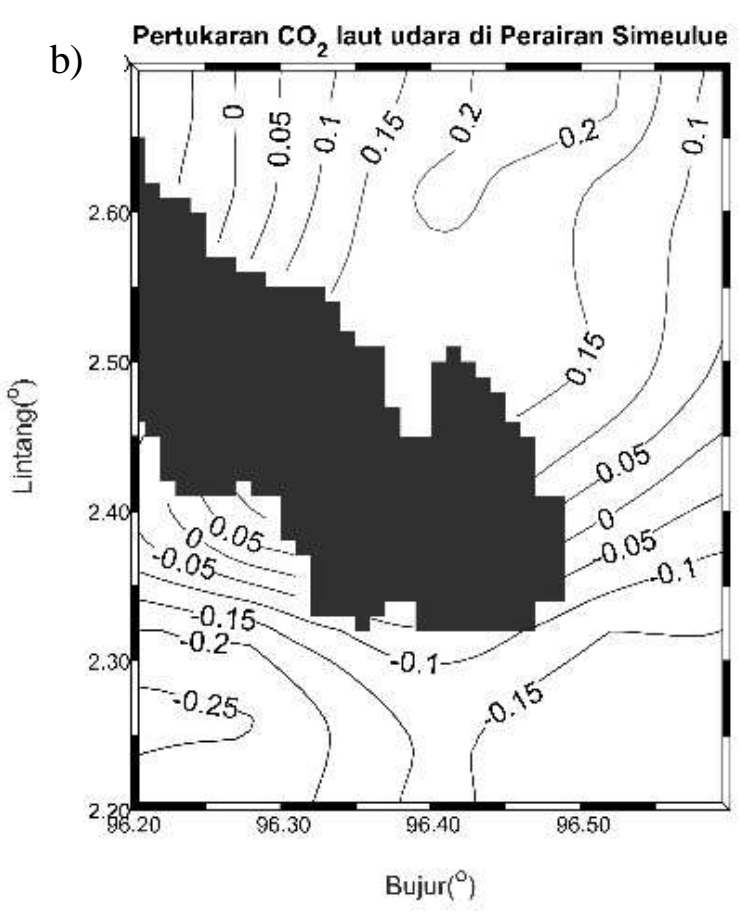

Gambar 4. Distribusi $\mathrm{pCO}_{2}$ laut dalam $\mathrm{ppm}$ (a) dan estimasi pertukaran $\mathrm{CO}_{2}$ laut-udara (b) dalam mol C/m $\mathrm{m}^{2} \mathrm{di}$ Perairan Simeulue 25-28 Juli 2017

Memperhatikan hubungan fluks karbondioksida dengan suhu maka dapat dilihat untuk wilayah perairan yang memiliki suhu lebih rendah cenderung menjadi tempat penyerapan karbon atau sink. Sementara itu untuk perairan yang suhunya cenderung lebih tinggi menjadi tempat pelepasan karbon atau source. Hal itu dapat diamati pada Gambar 3a. dan Gambar 4b. Fakta tersebut didukung oleh pernyataan Millero (2005) yang menyebutkan bahwa pertukaran karbon-dioksida antara laut dan udara sangat dipengaruhi oleh suhu permukaan laut dibanding dengan salinitas.

Pada perairan yang langsung berhadapan dengan Samudra Hindia memiliki rentang suhu $29-30,2^{\circ} \mathrm{C}$ lain halnya dengan perairan pada sisi sebaliknya rentang suhunya adalah $30-30,5^{\circ} \mathrm{C}$. Hal tersebut sangat berpengaruh terhadap fluks karbondioksidanya. Sehingga pada perairan yang berhadapan dengan Samudra Hindia menjadi tempat penyerapan karbondioksida (sink) dan pada perairan sisi sebaliknya menjadi tempat pelepasan karbondioksida (source). Argumen ini didasarkan sematamata pada perhitungan pada persamaan (1), bahwa sink dan source sangat ditentukan oleh suhu, salinitas dan perbedaan konsentrasi $\mathrm{CO}_{2}$ laut-udara. Jika selisihnya negatif maka sebagai sink dan jika selisihnya positif maka sebagai source.

\section{KESIMPULAN}

Selama musim panas Asia bulan Juli Perairan Simeulue bagian barat atau yang berhadapan langsung dengan Samudra Hindia memiliki suhu yang relatif rendah dan peningkatan salinitas. Hal tersebut menyebabkan terjadinya penyerapan karbondioksida dengan nilai antara $-0,05$ hingga $-0,25 \mathrm{~mol} \mathrm{C} / \mathrm{m}^{2}$ hari di bagian barat Pulau Simeulue. Sebaliknya di wilayah timur Perairan Simeulue menjadi tempat pelepasan karbondioksida dari laut ke atmosfer dengan besaran 0,05 hingga $0,2 \mathrm{~mol} \mathrm{C} / \mathrm{m}^{2}$ hari.

\section{UCAPAN TERIMAKASIH}

Terima kasih penulis ucapkan kepada Pusat Penelitian Oseanografi, Lembaga Ilmu Pengetahuan Indonesia atas kesempatan yang diberikan untuk pe-ngambilan data di Simeulue, Aceh. Ucapan terima kasih juga penulis sampaikan kepada seluruh tim EWIN 2017 \#Coastal Chapter. Ide dan penulisan makalah merupakan bagian dari Riset dan Inovasi ITB 2017 yang berjudul "Sistem Arus Laut Indonesia dan Pengaruhnya pada Produksi Perikanan Laut Nasional".

\section{DAFTAR PUSTAKA}

Eltrik, M. 2016. Analisis pertumbuhan linier koral dan korelasinya dengan variasi suhu permukaan laut tahunan studi kasus: koral dari perairan pulau Simeulue. Tugas Akhir Program 
Studi Oseanografi. Institut Teknologi Bandung. $72 \mathrm{hlm}$.

Environmental Systems Research Institute. 2001. Geostatistical analyst: Statistical tools for data exploration, modeling, and advanced surface generation. ESRI. USA. 23 p.

Ho, D.T., C.S. Law, M.J. Smith, P. Schlosser, M. Harvey, and P. Hill. 2006. Measurements of air-sea gas exchange at high wind speeds in the Southern Ocean: Implications for global parameterizations. Geophys. Res. Lett., 33(16): 1-6. https://doi.org/10.1029\%2F2006GL0 26817

Mardiansyah, W. dan I. Iskandar. 2014. Variasi temporal Arus Wyrtki di Samudera Hindia dan hubungannya dengan fenomena Indian Ocean Dipole. J. Segara, 10(2): 98-105.

Masumoto, Y., H. Hase, Y. Kuroda, H. Matsuura. dan K. Takeuchi. 2005. Intraseasonal variability in the upper layer currents observed in the eastern equatorial Indian Ocean. Geophys. Res. Lett., 32(2): 1-4. https://doi.org/10.1029/2004GL02189 6
Millero, F.J. 2005. Chemical Oceanography. Ed. 3th. United State. $242-246$ pp.

Percepatan Pembangunan Sanitasi Pemukiman Simeulue (PPSP). 2013. Buku Putih Sanitasi Kabupaten Simeulue Tahun 2013. Laporan. Dinas Pekerjaan Umum Kab. Simeulue. $18 \mathrm{hlm}$.

Rahmantya, K.F., D. Wibowo., W.A. Somad, H. Nainggolan, A.D. Asianto dan U. Nugroho. 2016. Profil sumber daya kelautan dan perikanan Kabupaten Simeulue. Pusat data, statistik dan informasi. Kementrian Kelautan dan Perikanan RI. Jakarta. $38 \mathrm{hlm}$.

Tomczak and J.S. Godfrey. 2001. Regional Oceanography: An Introduction pdf version 1.0, The Flinders University of South Australia, Australia, 183 pp.

Wanninkhof, R. 1992. Relationship between wind speed and gas exchange over the ocean. J. of Geophys. Res., 97(C5): 7373-7382.

https://doi.org/10.1029/92JC00188
Received : 18 April 2019
Reviewed :09 October 2019
Accepted :05 December 2019 